\title{
MODEL PEMBELAJARAN KOOPERATIF TIPE GROUP INVESTIGATION UNTUK MENINGKATKAN MOTIVASI BELAJAR DAN HASIL BELAJAR SISWA
}

\author{
Oleh: \\ I Made Putra Aryana \\ Fakultas Dharma Acarya Institut Hindu Dharma Negeri Denpasar \\ madeputra84@gmail.com
}

diterima 20 Desember 2018, direvisi 5 Januari 2019, diterbitkan 29 April 2019

\begin{abstract}
In essence teaching and learning activities are a process of interaction or reciprocal relations between the teacher and students in the learning unit. For this reason, an effort is needed in order to improve the quality of education and teaching, one of which is to choose a strategy or method for delivering learning material so that students can improve their learning achievement. Literature study was conducted to find information about learning, especially the cooperative learning model type Group Investigation (GI). So that by applying the GI cooperative model can improve learning outcomes and student learning motivation. Learning outcomes are what is achieved by students by involving all the potential they have after the students carry out learning activities. Achievement of these learning outcomes can be known by holding an assessment of learning outcomes tests. Motivation to learn means a tendency and high enthusiasm or a great desire for learning. Cooperative learning is a model of teaching where students learn in small groups and have different abilities. Group type Investigation (GI) learning is the most complex learning model. The core steps of the Investigastion Group's learning model are as follows. (1). The teacher forms groups and calls each group leader to receive assignments / material. (2). Each group leader returns to his group and then discusses in depth the tasks that are obtained with the group members. (3). After being considered enough time for group discussion, each group represented by the spokesperson delivered the results of the group discussion that was listened to by all students. (4). The results of the discussion were read by each group alternately by each group until all groups had their turn to deliver the results of the discussion. The application of cooperative learning model group investigation type can be used as one of the learning models in an effort to improve learning outcomes and student motivation in the learning process. Each stage in investigation group learning is a good assessment material related to teacher observation of student activities and the works produced by students while undergoing the learning process.
\end{abstract}

Keywords: Belajar, Pembelajaran kooperatif, Kooperatif Grup Investigation. 


\section{Pendahuluan}

Pendidikan adalah usaha sadar dan terencana untuk mewujudkan suasana belajar dan proses pembelajaran agar peserta didik secara aktif mengembangkan potensi dirinya untuk memiliki kemampuan spiritual keagamaan, pengendalian diri, kepribadian, kecerdasan, akhlak mulia serta keterampilan yang diperlukan dirinya, masyarakat, bangsa dan negara

(https://www.slideshare.net/srijadi/uu -no-20-2003-sistem-pendidikannasional). Salah satu tugas pokok guru adalah melakukan pembelajaran (mulai dari merancang, menyajikan, dan sampai kepada evaluasi proses dan hasil pembelajaran) agar diperoleh hasil pembelajaran yang sesuai dengan tujuan yang dirancangkan.

Guru mengemban tugas yang berat untuk tercapainya tujuan pendidikan nasional yaitu meningkatkan kualitas manusia Indonesia, manusia seutuhnya yang beriman dan bertakwa terhadap Tuhan Yang Maha Esa, berbudi pekerti luhur, berkepribadian, berdisiplin, bekerja keras, tangguh, bertanggung jawab, mandiri, cerdas dan terampil serta sehat jasmani dan rohani, juga harus mampu menumbuhkan dan memperdalam rasa cinta terhadap tanah air, mempertebal semangat kebangsaan dan rasa kesetiakawanan sosial. Sejalan dengan itu pendidikan nasional akan mampu mewujudkan manusia-manusia pembangunan dan rnembangun dirinya sendiri serta bertanggung jawab atas pembangunan bangsa. Pendidikan agama juga membentukan moral dan karakter, sehingga dengan pemahaman agama yang baik dan benar dapat terhindar dari pengaruh lingkungan yang terjadi belakangan ini seperti tawuran pelajar.

Demikian pula Pendidikan Agama Hindu merupakan suatu sarana dalam menumbuh kembangkan dan meningkatkan kualitas Sradha dan Bhakti melalui pemberian, pemupukan, penghayatan dan pengamalan ajaran agama serta membangun insan Hindu yang dapat mewujudkan nilai-nilai Moksartham Jagathita dalam kehidupannya. Harapan ideal tersebut akan tercapi apabila di sekolah dalam proses pembelajaran memberikan ruang kepada peserta didik untuk mengembangkan potensi yang mereka miliki dengan menggunakan strategi pembelajaran yang relevan dengan karakteristik dan kebutuhannya.

Kualitas pembelajaran dapat dilihat dari dua sisi yang sama pentingnya, yakni sisi proses dan sisi hasil belajar (Sanjaya, 2010: 2). Proses belajar berkaitan dengan pola prilaku siswa dalam mempelajari bahan pelajaran, sedangkan hasi belajar berkaitan dengan perubahan perilaku yang diperoleh sebagai pengaruh dari proses belajar.

Pada hakikatnya kegiatan belajar mengajar adalah suatu proses interaksi atau hubungan timbal balik antara guru dan siswa dalam satuan pembelajaran. Guru sebagai salah satu komponen dalam proses belajar menganjar merupakan pemegang peran yang sangat penting. Guru bukan hanya sekedar penyampai materi saja, tetapi lebih dari itu guru dapat dikatakan sebagai sentral pembelajaran.

Untuk itu diperlukan suatu upaya dalam rangka meningkatkan mutu pendidikan dan pengajaran salah satunya adalah dengan memilih 
strategi atau cara dalam menyampaikan materi pelajaran agar diperoleh peningkatan prestasi belajar siswa. Misalnya dengan membimbing siswa untuk bersamasama terlibat aktif dalam proses pembelajaran dan mampu membantu siswa berkembang sesuai dengan taraf intelektualnya akan lebih menguatkan pemahaman siswa terhadap konsep yang diajarkan. Pemahaman ini memerlukan minat dan motivasi. Tanpa adanya minat menandakan bahwa siswa tidak mempunyai motivasi untuk belajar. Untuk itu, guru harus memberikan suntikan dalam bentuk motivasi sehingga dengan bantuan itu anak didik dapat keluar dari kesulitan belajar.

\section{PEMBAHASAN}

Belajar (Syah, 2015: 63) adalah kegiatan yang berproses dan merupakan unsur yang sangat fundamental dalam penyelenggaraan setiap jenis dan jenjang pendidikan. Berhasil dan gagalnya pencapaian tujuan pendidikan bergantung pada proses belajar yang dialami siswa baik ketika berada di sekolah maupun di lingkungan rumah atau keluarganya sendiri. Pemahaman yang benar tentang arti belajar dengan segala aspek, bentuk, dan manifestasinya mutlak diperlukan oleh para pendidik. Rumusan belajr ada tiga (Biggs dalam Syah, 2015) yaitu: pertama belajar secara kuantitatif berarti kegiatan pengisian atau pengembangan kemampuan kognitif dengan fakta sebanyakbanyaknya. Kedua bekajar secara institusional berarti belajar dipandang sebagai proses validasi (pengabsahan) terhadap penguasaan siswa atas materi-materi yang telah dipelajari. Terakhir belajar secara kualitatif (tinjauan mutu)ialah proses memperoleh arti-arti dalam pemahaman-pemahaman serta caracara menafsirkan dunia disekeliling siswa. Belajar dalam hal ini difokuskan tercapainya daya pikir dan tindakan yang berkualitas untuk memecahkan masalah-masalah yang kini dan nanti dihadapi siswa.

Belajar dapat membawa suatu perubahan pada individu yang belajar. Perubahan ini merupakan pengalaman tingkah laku dari yang kurang baik menjadi lebih baik. Pengalaman dalam belajar merupakan pengalaman yang dituju pada hasil yang akan dicapai siswa dalam proses belajar di sekolah. Menurut Poerwodarminto (1991), prestasi/hasil belajar adalah hasil yang dicapai (dilakukan, dikerjakan), dalam hal ini hasil belajar merupakan hasil pekerjaan, hasil penciptaan oleh seseorang yang diperoleh dengan ketelitian kerja serta perjuangan yang membutuhkan pikiran.

Berdasarkan uraian diatas dapat dikatakan bahwa hasil belajar adalah apa yang dicapai oleh siswa dengan melibatkan seluruh potensi yang dimilikinya setelah siswa itu melakukan kegiatan belajar. Pencapaian hasil belajar tersebut dapat diketahui dengan mengadakan penilaian tes hasil belajar. Penilaian diadakan untuk rnengetahui sejauh mana siswa telah berhasil mengikuti pelajaran yang diberikan oleh guru. Di samping itu guru dapat mengetahui sejauh mana keberhasilan guru dalam proses belajar mengajar di sekolah sehingga sekolah menentukan batas hasil belajar.

Motivasi (Djamarah, 2002: 114) adalah suatu perubahan energy pada diri seseorang yang ditandani 
dengan timbulnya afektif (perasaan) dan reaksi untuk mencapai tujuan. Perubahan energy pada diri sesorang itu berbentuk suatu aktivitas nyata berupa kegiatan fisik. Karena seseorang mempunyai tujuan tertentu dari aktivitasnya, maka seseorang mempunyai motivasi yang kuatuntuk mencapaiya dengn segala upaya yang dapat ia lakukan untuk mencapainya. Dalam proses belajar motivasi sangat diperlukan, sebab seseorang yang tidak mempunyai motivasi belajar, tidak akan mungkin melakukan aktivitas belajar. Sesuatu yang dikerjakan tidak menyentuh kebutuhannya.

Senada dengan Djamarah, Syah (2015: 152) menyebut motivasi sebagai minat. Secara sederhana minat berarti kecenderungan dan kegairahan yang tinggi atau keinginan yang besar terhadap sesuatu. Pengertian dasar motivasi ialah keadaan internal organisme baik manusia maupun hewan yang mendorongnya untuk berbuat sesuatu. Dalam hal ini motivasi berarti pemasok daya untuk bertingkah laku terarah.

Jadi motivasi adalah suatu kondisi yang mendorong seseorang untuk berbuat sesuatu dalam mencapai tujuan tertentu.

\section{Teori Teori belajar}

\section{Teori Belajar Konstruktivisme}

Gagasan

pokok

konstruktivisme pertama kali

diungkapkan oleh Cambatissta Vico tahun 1970 (dalam Suparno, 1997: 20) menyatakan bahwa: mengetahui berarti bagaimana membuat sesuatu. Hal ini berarti bahwa seseorang itu baru mengetahui sesuatu jika ia dapat menjelaskan unsur-unsur apa yang membangun sesuatu itu. Hanya Tuhan sajalah yang dapat mengerti alam raya ini, karena hanya dia yang tahu bagaimana membuatnya dan dari apa ia membuatnya. Sementara, orang hanya mengetahui sesuatu itu yang telah dikonstruksinya.

Berkaitan dengan ungkapan diatas dalam hubungannya dengan dunia pendidikan teori konstruktivisme yang banyak berpengaruh dalam dunia pendidikan dewasa ini adalah teori belajar Piaget dan Viygotsky.

\section{Teori Belajar Piaget}

Piaget adalah salah satu tokoh konstruktivisme dari Swiss, ia berpendapat bahwa anak membangun sendiri pengetahuan dari pengalaman sendiri. Pengetahuan timbul dari pengalamannya sendiri. Pengetahuan timbul dari tindakan dan sebagian besar perkembangan kognitif bergantung pada seberapa jauh anak aktif memanipulasi dan aktif berinteraksi dengan lingkungannya (Piaget dalam Widada, 1999 : 21).

Piaget menyatakan skema merupakan struktur mental seseorang yang menggambarkan adanya keterhubungan konsep-konsep tertentu. Struktur kognitif (skema) terbentuk pada waktu seseorang berinteraksi dengan lingkungan. Skema berkembang sejalan dengan perkembangan kognitif yang dipengaruhi oleh tiga proses dasar, yaitu asimilasi, akomodasi, dan ekuilibrasi. Dalam proses asimilasi seseorang menggunakan sruktur kognitif (skema) yang sudah ada untuk menanggapi pengetahuan baru yang diterima dengan skema yang telah ada.

Dalam pembelajaran, Piaget menekankan pembelajaran melalui penemuan, pengalaman-pengalaman nyata dan memanipulasi langsung 
alat, bahan atau media belajar yang lain. Guru mempersiapkan lingkungan yang memungkinkan siswa dapat memperoleh pengalaman belajar yang luas. Guru bertindak sebagai fasilitator, model serta sebagai nara sumber yang tidak otoriter.

\section{Teori Belajar Vygotsky}

Widada (1998: 21) inti teori konstruktivis Vygotsky adalah integrasi antara aspek internal dan eksternal yang penekanannya pada lingkungan sosial belajar. Vygotsky lebih menekankan pada sosio cultural dalam pembelajaran, yakni interaksi sosial, khususnya melalui dialog dan komunikasi verbal. Menurut Vygotsky, interaksi sosial, terlebih bahasa, berpengaruh besar terhadap pembelajaran seseorang. Ini berarti dalam belajar selain diperlukan keaktifan siswa juga dipentingkan lingkungan sosial dengan demikian inti dari konstruktivisme Vygotsky adalah integrasi dari aspek internal dengan eksternal serta penekanannya pada lingkungan sosial siswa.

Vygotsky yakin bahwa pembelajaran terjadi apabila siswa belajar menangani tugas-tugas yang belum dipelajari namun tugas-tugas itu masih berada dalam daerah jangkauannya. Fungsi mental yang lebih tinggi pada umumnya muncul dalam percakapan atau kerja sama antar individu sebelum fungsi mental yang lebih tinggi itu terserap kedalam individu tersebut. Dalam pembelajaran, Teori konstruktivisme Vygotsky memiliki implikasi sebagai berikut.

1. Dikehendakinya seting kelas berbentuk pembelajaran kooperatif antar siswa, menurut Vygotsky setiap anak mempunyai apa yang disebut zona perkembangan proksimal (zone of proximal development) yang oleh Vygotsky di definisikan sebagai jarak atau selisih antara apa yang bisa dilakukan seseorang anak secara independen dengan apa yang bisa dicapai oleh anak tersebut jika ia mendapat bantuan seorang yang lebih kompeten.

2. Pendekatan kontrukstivisme Vygotsky dalam pembelajaran menekankan scaffolding, yang berarti siswa semakin lama semakin bertanggung jawab terhadap pembelajarannya sendiri (Suparno, 1997 : 72).

\section{Pembelajaran Kooperatif}

Belajar adalah suatu proses yang ditandai dengan perubahan pada diri siswa, dan perubahan itu merupakan hasil belajar yang melibatkan segi jasmani dan rohani yang menghasilkan perubahanperubahan dalam hal pengetahuan, pemahaman, keterampilan, sikap dan tingkah laku, serta semua aspek yang ada dalam individu.

Model pembelajaran kooperatif sangat berbeda dengan pengajaran langsung. Model pembelajaran ini dapat diguanakan untuk mengajarkan materi yang agak kompleks dan yang lebih panjang, dapat membantu guru untuk mencapai tujuan. Pengajaran yang berdimensikan sosial dan hubungan antar manusia. Belajar secara kooperatif dikembangkan berdasarkan teori belajar kognitifkonstrukivitas dan teori belajar siswa.

Pembelajaran kooperatif merupakan suatu model pengajaran dimana siswa belajar dalam kelompok-kelompok kecil dan memiliki kemampuan berbeda. 
Dalam menyelesaikan tugas kelompok setiap anggota saling bekerja sama dan membantu untuk memahami suatu bahan pelajaran. Belajar belum sesuai jika salah satu teman dalam kelompok belum menguasi pembelajaran (Jatmiko, 2005:7). Pada pembelajaran kooperatif siswa bekerja sama menyumbangkan gagasan pikirannya untuk kelompok belajarnya dan bertanggung jawab untuk kelompok. Dimana keberhasilan belajar dicapai jika hanya seluruh kelompok mencapai kebeharsilannya.

\section{Kurniawan}

dalam

https://kurniawanbudi04.wordpress.c om/2013/05/27/model-pembelajarankooperatif-cooperative-learning/ menyebutkan pembelajaran kooperatif adalah pendekatan pembelajaran yang berfokus pada penggunaan kelompok kecil siswa untuk bekerja sama dalam memaksimalkan kondisi belajar untuk mencapai tujuan belajar. 1 . Saling ketergantungan positif berarti guru menciptakan suasana yang mendorong agar siswa merasa saling membutuhkan atau yang biasa disebut dengan saling ketergantungan positif yang dapat dicapai melalui : saling ketergantungan mencapai tujuan, saling ketergantungan menyelesaikan tugas, saling ketergantungan bahan atau sumber, saling ketergantungan peran, saling ketergantungan hadiah. 2. Interaksi tatap muka, dalam hal ini dapat memaksa siswa saling bertatap muka sehingga mereka akan berdialog. Dialog tidak hanya dilakukan dengan guru tetapi dengan teman sebaya juga karena biasanya siswa akan lebih luwes, lebih mudah belajarnya dengan teman sebaya. 3 . Akuntabilitas

Pembelajaran individual, kooperatif menampilkan wujudnya dalam belajar kelompok. Penilaian ditunjukkan untuk mengetahui penguasaan siswa terhadap materi pelajaran secara individual. Hasil penilaian ini selanjutnya disampaikan oleh guru kepada kelompok agar semua kelompok mengetahui siapa kelompok yang memerlukan bantuan dan siapa yang dapat memberikan bantuan,maksudnya yang dapat mengajarkan kepada temannya. Nilai kelompok tersebut harus didasarkan pada rata-rata, karena itu anggota kelompok harus memberikan kontribusi untuk kelompnya. Intinya yang dimaksud dengan akuntabilitas individual adalah penilaian kelompok yang didasarkan pada ratarata penguasaan semua anggota secara individual. 4. Keterampilan menjalin hubungan antar pribadi, Keterampilan sosial dalam menjalin hubungan antar siswa harus diajarkan. Siswa yang tidak dapat menjalin hubungan antar pribadi akan memperoleh teguran dari guru juga siswa lainnya.

Di samping model pembelajaran kooperatif dikembangkan untuk meningkatkan hasil belajar akademik, model pembelajaran ini juga efektif untuk mengembangkan keterampilan sosial siswa. Beberapa ahli berpendapat bahwa model ini unggul dalam membantu siswa memahami konsepkonsep yang sulit. Para pengembang model ini telah menunjukkan bahwa model struktur penghargaan kooperatif telah dapat meningkatkan penilaian siswa pada belajar akademik dan perubahan norma yang berhubungan dengan hasil belajar. Dalam banyak kasus, norma budaya anak muda sebenarnya tidak menyukai siswa-siswa yang 
menonjol secara akademis. Salvin dan pakar lain telah berusaha untuk mengubah norma ini melalui penggunaan pembelajaran kooperatif.

Pembelajaran kooperatif mengubah norma yang berhubungan dengan hasil belajar, pembelajaran kooperatif dapat memberi keuntungan baik pada siswa kelompok bawah maupun kelompok atas yang bekerja sama menyelesaikan tugas-tugas akademik. Siswa kelompok atas akan menjadi tutor membutuhkan pemikiran lebih mendalam tentang hubungan ide-ide yang terdapat didalam materi tertentu. Tujuan penting lain dari pembelajaran kooperatif adalah untuk mengajarkan kepada siswa keterampilan bekerjasama dan kolaborasi. Keterampilan ini sangat penting untuk dimiliki didalam masyarakat yang secara budaya semakin beragam, yang saing bergantung satu sama lain.

Terdapat enam langkah utama atau tahapan di dalam pelajaran yang menggunakan pembelajaran kooperatif. Pelajaran dimulai dengan guru menyampaikan tujuan pembelajaran dan memotivasi untuk belajar. Fase ini diikuti oleh penyajian informasi; seringkali dengan bahan bacaan daripada secara verbal. Selanjutnya siswa dikelompokkan ke dalam tim-tim belajar. Tahap ini diikuti bimbingan guru pada saat siswa bekerja bersama untuk menyelesaikan tugas bersama mereka. Fase terakhir pembelajaran kooperatif meliputi presentasi hasil akhir kerja kelompok, atau evaluasi tentang apa yang telah mereka pelajari dan memberi penghargaan terhadap usaha-usaha kelompok atau individu.

\section{Model pembelajaran Cooperative tife Group Investigastion}

Pembelajaran tipe Group Investigation (GI) merupakan metode pembe;lajaran dengan siswa belajar secara kelompok, kelompok belajar terbentuk berdasarkan topic yang dipilkih siswa http://yudiwiratama.blogspot.com/2014/01/mod elpembelajaran-kooperatif-tipe.html. Dalam pembelajaran kooperatif GI, siswa dibagi menjadi beberapak kelompok dengan anggota 2-6 siswa yanh heterogen, kelompok melakukan penyelidikan yang mendalam terhadap topic yang dilihnya selanjutnya menyiapkan dan mempresentasikan laporannya di depan kelas.

Sintaks Pembelajaran kooperatif tipe GI (Yudi wiratam blogspot) terdiri dari beberapa tahapan yaitu: 1. Memusatkan perhatian siswa, 2. Mengidentifikasi topic dan membagi siswa ke dalam kelompok, 3. Merencanakn tugas, 4. Membuat penyelidikan, 5 . Mempresentasikan tugas, dan 6 . Evaluasi pembelajaran.

Cooperative learning dengan tipe group investigation (GI) apabila diterapkan pada Proses belajar mengajar dapat memunculkan keterampilan proses sains secara optimal, sehingga dapat mengetahui dari pengetahuan yang dimilikinya. Dalam kitab Manawa Dharma Sastra, menyebutkan tentang pembelajaran yang benar akan dapat mencapai keadaan yang abadi (kebebasan absolut) sesuai dengan bunyi sloka berikut ini (Pudja,1995;61):

Tesu samyag warta mano, gacchatya mara lokatam

Yatha samkalpitamccena, sarwam kamansamasnute 
ADI WIDYA: Jurnal Pendidikan Dasar

(MDS, II.5)

Terjemahannya :

Ia yang tekun melakukan tugas-tugas yang telah ditentukan ini dengan caracara yang benar mencapai keadaan yang abadi walaupun dalam kehidupan ini sekalipun terpenuhilah segala keinginan-keinginan yang mungkin diidamidamkannya.

Segala bentuk tugas-tugas mulia dalam pembelajaran kepada siswa merupakan sebuah yadnya yang tinggi sehingga segala keinginan yang kita idam-idamkan dapat tercapai, tentunya dengan cara yang sesuai dengan ketentuan yang ditetapkan dalam weda dan pengerjaannya bukan didasarkan atas niat untuk memperoleh pahala.

Model Pembelajaran Group Investigastion adalah suatu tipe model pembelajaran kooperatif. Model pembelajaran ini menggali potensi individu murid dalam kelompok dan keterampilan membahas pertanyaan/pernyataan secara mendalam di masing-masing kelompok.

Pada model pembelajaran Group Investigastion siswa dibentuk menjadi beberapa kelompok yang diwakili ketua kelompok untuk mendapat tugas yang berbeda antar kelompok dari guru, kemudian masing-masing siswa dalam kelompok membahas tugas yang diperoleh secara mendalam disertai dengan penemuan-penemuan.

Model Pembelajaran Group Investigastion melatih siswa untuk lebih tanggap menerima pesan dari orang lain melalui diskusi kelompok. Model pembelajaran ini juga melatih siswa menggunakan potensi dan daya imajinasi untuki membahas tugas yang diperoleh.

Adapun Langkahlangkah model pembelajaran Group Investigastion adalah sebagai berikut.

1. Guru menyampaikan materi yang akan disajikan.

2. Guru membentuk kelompok-kelompok dan memanggil masing-masing ketua kelompok untuk menerima tugas/materi.

3. Masing-masing ketua kelompok kembali ke kelompoknya masingmasing kemudian membahas secara mendalam tugas yang diperoleh bersama anggota kelompoknya.

4. Setelah dianggap cukup waktu diskusi kelompok, masing-masing kelompok yang diwakili oleh juru bicara menyampaikan hasil pembahasan kelompok yang disimak oleh seluruh siswa.

5. Hasil pembahasan dibacakan oleh masingmasing kelompok secara bergantian oleh masingmasing kelompok sampai semua kelompok mendapat giliran menyampaikan hasil pembahasannya.

6. Evaluasi

7. Penutup.

Penerapan pembelajaran dengan model Group Investigastion adalah, (a) siswa secara berkelompok melakukan investigation yaitu siswa mengidentifikasi pembelajaran untuk menemukan pengetahuan/materi, (b) 
siswa secara berkelompok melakukan inquiry yaitu, merumuskan dan menemukan pembahasan terhadap materi, (c) constructivism yaitu dengan arahan dari guru setiap siswa dalam kelompok menjawab pertanyaan yang terdapat pada bola dan dari pertanyaan tersebut siswa dapat mengkonstruksi tujuan pembelajaran tersebut.

Pendidikan memegang peranan yang cukup penting dalam mewujudkan generasi anak bangsa yang potensial dan bermutu. Salah satu faktor pendukung keberhasilan dalam bidang pendidikan dipengaruhi oleh cara belajar mengajar pada saat ini, yang mana praktek-praktek pembelajaran di lapangan cenderung masih mengabaikan gagasan dan kemampuan berfikir aktif peserta didik. Perencanaan dan implementasi pembelajaran yang dilakukan guru tampaknya masih menggunakan metode transfer informasi, sedangkan peserta didik belajar hanya berdasarkan catatan, perintah, dan tugas-tugas dari guru semata. Pengalaman peserta didik sangat mempengaruhi prestasi belajar mereka. Salah satu faktor yang menunjang pengalaman peserta didik adalah aktivitas belajar, oleh karena itu proses pembelajaran harus dirancang sedemikian rupa untuk merangsang aktivitas belajar siswa secara optimal. Dengan aktivitas belajar yang optimal maka prestasi belajarpun akan meningkat.

Kunci utama dalam peningkatan kualitas pendidikan terletak pada mutu gurunya, oleh karena itu para pelaku pendidikan terutama para guru dituntut untuk menguasai dan berinovasi baik dalam penggunaan metode pembelajaran, serta sarana dan prasarana yang tersedia demi tercapainya peningkatan kualitas pendidikan. Selain itu guru sebagai inovator yang mempunyai tanggung jawab untuk melaksanakan inovasi dalam penyelenggaraan pendidikan di sekolah. (Hamalik, 2001:44), guru memiliki berbagai tanggung jawab dan tugas yang harus dilaksanakan sesuai dengan tuntutan profesi guru. Tugas utama dan terpenting yang menjadi tanggung jawab seorang guru adalah merangsang, membimbing dan memajukan siswa dalam proses belajar. Segala usaha ke arah itu harus dirancang dan dilaksanakan. Guru yang berkesan dalam menjalankan tugasnya adalah guru yang berhasil menjadikan siswanya termotivasi dalam pelajaran. Karena itu dalam pengajaran, guru harus berusaha memahami makna motivasi belajar itu sendiri dan mengembangkan serta menggerakkan motivasi pembelajaran siswa ke tahap yang maksimum.

Selain itu pembelajaran akan lebih bermakna jika anak mengalami apa yang dipelajarinya, bukan mengetahuinya. Pembelajaran yang berorientasi target penguasaan materi terbukti berhasil dalam kompetisi mengingat dalam jangka pendek, tetapi gagal dalam membekali anak memecahkan masalah dalam kehidupan jangka panjang. Pendekatan kontekstual merupakan konsep belajar yang membantu guru mengaitkan antara materi yang diajarkannya dengan situasi di dunia nyata siswa dan mendorong siswa membuat hubungan antara pengetahuan yang dimilikinya dengan penerapannya dalam kehidupan mereka sebagai anggota keluarga dan masyarakat. 
Pembelajaran kooperatif lebih menekankan interaksi antar siswa. Dari sini siswa akan melakukan komunikasi aktif dengan sesama temannya. Dengan komunikasi tersebut diharapkan siswa dapat menguasai materi pelajaran dengan mudah karena siswa lebih mudah memahami penjelasan dari kawannya dibanding penjelasan dari guru karena taraf pengetahuan serta pemikiran mereka lebih sejalan dan sepadan. Selain itu, penelitian juga menunjukkan bahwa pembelajaran kooperatif memiliki dampak yang amat positif terhadap siswa yang rendah hasil belajarnya.

Pembelajaran dengan model Group Investigastion, menggunakan tiga penerapan pembelajaran antara lain: pengetahuan dibangun sedikit demi sedikit yang hasilnya diperluas melalui konteks yang terbatas melalui pengalaman nyata (constructivism), pengetahuan dan keterampilan yang diperoleh siswa diharapkan bukan hasil mengingat seperangkat fakta-fakta, tetapi hasil dari menemukan sendiri (inquiry), pengetahuan yang dimiliki seseorang, mengkonfirmasikan apa yang sudah diketahui dan mengarahkan perhatian pada aspek yang belum diketahui. Di dalam model pembelajaran Group Investigastion, strategi memperoleh dan pendalaman pengetahuan lebih diutamakan dibandingkan seberapa banyak siswa memperoleh dan mengingat pengetahuan tersebut.

\section{Penilaian hasil belajar}

Evaluasi merupakan hal yang tidak terpisahkan dari penyelenggaraan pembelajaran secara keseluruhan. Evaluasi diselenggarakan untuk mencapai sejumlah tujuan pembelajaran yang
: http://ejournal.ihdn.ac.id/index.php/AW

telah diidentifikasikan dan dirumuskan berdasarkan telaah mendalam terhadap kebutuhan yang perlu dipenuhi.

Melalui evaluasi diperoleh informasi berkaitan dengan kemampuan yang dimiliki dalam bidang tertentu. Informasi yang diperoleh beisaberupa bahan ajar, metode dan teknik pembelajaran, penyusunan dan penyelenggaraan tes, serta latihan-latihan yang dilakukan. Informasi itu dikaji sebagai dasar untuk menentukan sasaran yang tepat dan dapat dipertanggungjawabkan yang berkualitas.

\section{Evaluasi pembelajaran}

Evaluasi (Asih: 275) dalam pengertian luas dapat diartikan sebagai proses merencanakan, memperoleh, dan menyediakan informasi atau data yang diperlukan sebagai dasar untuk membuat alternative keputusan. Dengan demikian, setiapkegiatan evaluasi atau penilaian merupakan proses yang sengaja direncanakan untuk memperoleh informasi atau data.

Melalui evaluasi, seorang pengajar dapat: (1) mengetahui apakah siswa mampu menguasai materi yang telah diajarkan, (2) bersikap sebagaimana yang diharapkan, (3) memiliki keterampilan tertentu, (4) mengetahui keberhasilan proses belajar mengajar yag telah dilaksanakan, dan (5) menentukan kebijakan selanjutnya.

\section{Pengukuran}

Evaluasi tidak sama dengan pengukuran (measurement), Wand dan Brown (dalam Asih: 274) menyatakan, "Measurement means the act or process of ascestaining the extent or quantity of something", yang artinya pengukuran adalah 
suatu tindakan atau proses untuk menentukan luas atau kuantitas daripada sesuatu.

Sekalipun ada perbedaan antara penilaian dan pengukuran, kedua hal tersebut tidak dapat dipisahkan karena keduanya memiliki hubungan yang sangat erat. Untuk mengadakan penilaian yang tepat terhadap sesuatu,kita harus melakukan pengukuran-pengukuran.

Misalnya, untuk menilai apakah seorang siswa dapat membaca dengan lancar atau tidak, kita perlu mengukur berapa jumlah kata yang dibacanya dalam satu menit, berapa kesalahan yang dibuatnya, dan sebagainya.

Pada prinsipnya, pengukuran pembelajaran adalah kegiatan yang dilakukan dalam proses pembelajaran untuk menentukan fakta kuantitatif yang disesuaikan dengan objek yang akan diukur.

\section{Penilaian}

Penilaian, menurut Arikunto (dalam Asih: 275), merupakan proses pembuatan keputusan terhadap suatu ukuran baik buruk yang bersifat kualitatif. Penilaian merupakan proses yang dilakukan melalui langkah-langkah perencanaan, penyusunan alat penilaian, pengumpulan informasi melalui sejumlah bukti yang menunjukkan hasil belajar peserta didik, pengolahan dan penggunaan informasi tentang hasil belajar peserta didik.

Penilaian dilaksanakan melalui berbai bentuk, seperti penilaian unjuk kerja (performance), penilaian sikap, penilaian tertulis (paper and pencil test), penilaian proyek, penilaian melalui kumpulan hasil kerja/karya peserta didik (portofolio), dan penilaian diri.

Tes
Tes adalah alat atau cara yang sistematis untuk mengukur sampel perilaku. Sebagai alat ukur, didalam tes terdapat berbagai item atau serangkaian tugas yang harus dikerjakan atau dijawab oleh peserta didik (Asih: 276). Tes yang baik adalah tes yag memenuhi persyaratan validasi (ketepatan/kesahihan) dan reliabilitas (ketepatan/keajegan). Test prestasi (achievement test) adalah tes yang digunakan untuk mengukur pencapaian siswa setelah mengikuti pembelajaran.

\section{Pembejaran Kooperatif Tipe GI untuk Meningkatkan Hasil Belajar dan Motivasi Belajar}

Menurut Asma dalam (yudi wiratama blogspot) pengembangan prses pembelajaran kooperatif tipe GI bertujuan untuk: 1. Pencapaian hasil belajar, strategi ini unggulan dalam membatu siswa dalam memahami konsep-konsep yang sulit, 2. Penerimaan terhadap keragaman, keragaman merupakan efek penting dalam pembelajaran kooperatif, 3 . Pengembangan keterampilan social, pembelajaran ini dapat mengajarkan keterampilan kerjasama dan kolaborasi.

Selanjutnya Rusman ((yudi wiratama blogspot) menyebutkan keunggulan pembelajran kooperatif tipe GI adalah: 1. Bentuk tanggung jawab dan kreatifitas siswa baik perorangan maupun kelompok, 2 . Membantu terjadinya pembagiaan tanggung jawab da berorientasi menuju pembentukan masusia social, 3. Mengaktifkan siswa dalam proses pembelajaran sehingga dapat membangun pengetahuan siswa.

Sehingga melalui berbagai macam jenis penilaian hasil belajar dapat diketahui sejauh mana siswa mampu memahami materi pelajaran 
yang disampiakan oleh guru, termasuk motivasi belajar siswa. Pembelajaran yang bervariasi dengan salah satu model pembelajaran kooperatif tipe Group Investigation (GI) akan mampu meningkatkan hasil belajar dan motivasi belajar siswa secara keseluruhan.

\section{SIMPULAN}

Pada model pembelajaran Group Investigastion siswa dibentuk menjadi beberapa kelompok yang diwakili ketua kelompok untuk mendapat tugas yang berbeda antar kelompok dari guru, kemudian masing-masing siswa dalam kelompok membahas tugas yang diperoleh secara mendalam disertai dengan penemuan-penemuan.

Model Pembelajaran Group Investigastion melatih siswa untuk lebih tanggap menerima pesan dari orang lain melalui diskusi kelompok. Model pembelajaran ini juga melatih siswa menggunakan potensi dan daya imajinasi untuki membahas tugas yang diperoleh.

$$
\text { Penerapan model }
$$

pembelajaran kooperatif tipe group investigation dapat digunakan sebagai salah satu model pembelajaran dalam upaya meningkatkan hasil belajar dan motivasi belajar siswa dalam proses pembelajaran. Dalam menerapkan model pembelajaran cooperative learning tipe group investigation, guru hendaknya memperhatikan beberapa hal seperti menyiapkan diri sebagai fasilitator dan mediator yang baik bagi siswa. Setiap tahapan dalam pembelajaran group investigation merupakan bahan penilaian baik itu terkait dengan observasi guru terhadap aktivitas siswa maupun karya-karya yang dihasilkan siswa ketika menjalani proses pembelajaran.

\section{DAFTAR PUSTAKA}

Arikunto, S. 2008. Penelitian Tindakan Kelas. Jakarta: Bumi Aksara

Asih. 2016. Strategi Pembelajaran Bahasa Indonesia. Bandung: Pustaka Setia.

Degeng, I Nyoman S. 1989 Ilmu Pengajaran Taxonomi Variabel, Jakarta: Dirjen Dikti, PPLPTK.

Depdiknas, 2003. Undang-Undang Republik Indonesia Nomor 20 Tahun 2003 tentang Sistim Pendidikan Nasional, Jakarta: Depdiknas.

Depdiknas, 2005. Peraturan Pemerintah Republik Indonesia Nomor 19 Tahun 2005 tentang Standar Nasional Pendidikan, Jakarta: Mendiknas.

Depdiknas, $2006 . \quad$ Pedoman Pelaksanaan Penelitian Tindakan Kelas, Jakarta: Dit Prodik Dirjen PMPTK.

Dimyati.Moerdjiono, 1994. Psikologi pendidikan, Yakarta: Fak.Psikologi UGM.

Djamarah, Drs Saiful Bahri. 2002. Psikologi Belajar. Jakarta: Pt Rineka Cipta.

Iskandar. 2009. Penelitian Tindakan Kelas. Jakarta: Gaung Persada (GP). Jatmiko, Budi dan Wardoyo. 2005. Contextual teching and Learning (CTL) Sebagai Salah Satu Alternative Pendekatan Pembelajaran. Jurnal Matematika, Sains, atau Pembelajaran. Volume 2, No. 4. Oktober

Muslich, Masnur. 2009. Melaksanakan PTK itu 
Mudah (Classroom Action Research). Jakarta: Buli Aksara.

Muslimin Ibrahim, 2000. Pembelajaran Kooperatif. Surabaya: Program Pascasarjana Unesa.

Netra,Ida bagus, 1983. Metodologi Penelitian. Singaraja: Biro Perbitan FKIP Unud.

Pudja, G. 1995, Manawa

Dharmasastra (Manu

Dharma Sastra).

Pemerintah Daerah Tingkat

II Badung.

Sanjaya, Wina. 2010. Penelitian

Tindakan Kelas. Jakarta: Kencana.

Sudirga Ida Bagus. 2009. Widya Upadeca Agama Hindu. Surabaya : Paramita

Supiyadi. 2005. Penelitian Tindakan

Kelas (Clasroom Action Research). Jakarta : Universitas Negeri Jakarta.

Syah, Muhibbin. 2015. Psikologi Belajar. Jakarta: Rajawali Pers.

Trianto, 2007. Pembelajaran Inovatif berorientasi knstruktivistik, Jakarta: Prestasi Pustaka.

Trianto. 2010. Mendesain Model Pembelajaran InovatifProgresif. Jakarta: Kencana
ADI WIDYA: Jurnal Pendidikan Dasar Volume. 4, Nomor 1 April 2019 ISSN: 2527-5445 : http://ejournal.ihdn.ac.id/index.php/AW

Wina Sanjaya, 2006. Pembelajaran dalam Implementasi KBK, Jakarta: Kencana Prenada Group.

https://www.slideshare.net/srijadi/uu -no-20-2003-sistempendidikan-nasional (diakses 26 November 2018).

https://kurniawanbudi04.wordpress.c om/2013/05/27/modelpembelajaran-kooperatifcooperative-learning/ (diakses 26 November 2018).

http://yudi-

wiratama.blogspot.com/2 014/01/modelpembelajar an-kooperatif-tipe.html (diakses 26 November 2018).

PF, K. A. P. D. (2017). The Empowerment Of Role Of The Family In Developing Character Of Environmental

Awareness In Elementary School-Age

Children. Vidyottama

Sanatana: International Journal of Hindu Science and Religious Studies, 1(1), 77-83. 